\title{
Physical properties of chilli growing soils of Khammam district
}

\section{R. SAIKUMAR AND C. NAGENDER RAO}

Received : 29.08.2016; Revised : 27.10.2016; Accepted : 20.11.2016

\section{MEMBERS OF RESEARCH FORUM}

Corresponding author :

R. SAIKUMAR, Department of Soil Science, College of Agriculture, Acharya N.G. Ranga Agricultural University, HYDERABAD (TELANGANA) INDIA

Email: saikumaragrico@gmail.com

Co-authors :

C. NAGENDER RAO, Department of Soil Science, College of Agriculture, Acharya N. G. Ranga Agricultural University, HYDERABAD (TELANGANA) INDIA

\section{Summary}

Fifteen profiles from the chilli growing areas of the district were chosen for the study. Soil samples were collected horizon-wise and analysed for physical properties. The soil texture varied from sandy loam to clay loam in surface horizons and sandy clay loam to clay loam to clay in sub-surface horizons. Bulk density and particle density of soils varied from 1.37 to 1.66 and 2.44 to $2.60 \mathrm{Mg} \mathrm{m}^{-3}$, respectively, the per cent aggregates greater than $0.25 \mathrm{~mm}$ and per cent aggregate stability ranged from 61.50 to $76.90,48.40$ to 64.60 , respectively, hydraulic conductivity of the soils ranged from $0.08 \mathrm{~cm} \mathrm{hr}^{-1}$ to $16.26 \mathrm{~cm} \mathrm{hr}^{-1}$, the infiltration was moderately rapid to moderately slow and slow, the water retention at 33 and $1500 \mathrm{~K} \mathrm{~Pa}$ was low, the available water content ranged from 4.21 per cent to 13.62 per cent and the available water storage capacity $\left(\mathrm{cm} \mathrm{m}^{-1}\right)$ was low, medium to high.

Key words : Horizon-wise, Physical properties

How to cite this article : Saikumar, R. and Rao, C. Nagender (2016). Physical properties of chilli growing soils of Khammam district. Asian J. Soil Sci., 11 (2) : 324-331 : DOI : 10.15740/HAS/AJSS/ 11.2/324-331. 